\title{
PEMBUKTIAN UNSUR NIAT DIKAITKAN DENGAN UNSUR MENS REA DALAM TINDAK PIDANA KORUPSI
}

\author{
Oleh : Kukun Abdul Syakur Munawar, S.H. ${ }^{*}$
}

\begin{abstract}
ABSTRAK
Untuk dapat mengungkap kesalahan dalam tindak pidana korupsi yang dilakukan oleh seorang terdakwa yang diajukan ke muka sidang, maka penuntut umum harus untuk dapat membuktikan kesalahan tersebut. sehingga penuntut umum dibebani untuk melakukan pembuktian dimana dengan alat-alat bukti yang diajukan itu membuat terang akan kebenaran suatu tindak pidana yang telah terjadi yang dilakukan oleh terdakwa yang dibawa di muka sidang. Jika unsur niat (kehendak) atau menghendaki dan mengetahui dalam kaitannya dengan unsur kesengajaan tidak dapat dibuktikan dengan jelas secara materiil karena memang maksud dan kehendak seseorang itu sulit untuk dibuktikan secara materiil maka pembuktian adanya unsur kesengajaan dalam pelaku melakukan tindakan korupsi yang melanggar hukum sehingga perbuatannya itu dapat dipertanggungjawabkan kepada si pelaku seringkali hanya dikaitkan dengan keadaan serta tindakan si pelaku pada waktu ia melakukan perbuatan melanggar hukum yang dituduhkan kepadanya tersebut. Unsur actus reus yaitu perbuatan harus didahulukan. Setelah diketahui adanya perbuatan pidana sesuai rumusan undang-undang selanjutnya barulah diselidiki tentang sikap batin pelaku atau unsur mens rea. Dengan demikian maka unsur perbuatan pidana harus didahulukan, selanjutnya apabila terbukti barulah mempertimbangkan tentang kesalahan terdakwa yang merupakan unsur pertanggungjawaban pidana
\end{abstract}

Kata Kunci ;

Pembuktian, Unsur Niat, Mens Rea

\section{ABSTRACT}

To be able to uncover errors in corruption committed by a defendant whose case was brought to trial, the public prosecutor must be able to prove to the error. so that the public prosecutor burdened to prove that the evidence submitted it makes light of the truth of a crime that has occurred committed by the accused are brought in session. If the element of intent (will) or willed and know in relation to the element of intent can not be proven clearly materially because the intention and will of a person it is difficult to prove materially the proof of a deliberate intention on the perpetrators commit acts of corruption that violate the law so the offense be accountable to the perpetrator is often only associated with the state as well as the actions the perpetrator at the time he was doing his alleged unlawful it. element of the actus reus is the act shall take precedence. Having in mind the existence of a criminal act in accordance formulation of legislation then investigated further on the inner attitude of the perpetrator or the element of mens rea. Thus, the elements of a criminal act must take precedence, then if it is proven then consider about the guilt of the accused which is an element of criminal liability.

Keywords ;

Proof, Elements Intent, Mens Rea

Alumni FH Unigal tahun 2011, Advokat, Staff Pengajar STISIP Bina Putera Banjar dan Mahasiswa Magister IImu Hukum Unsoed Purwokerto 


\section{PENDAHULUAN}

\section{I.1. Latar Belakang}

Dalam mengungkap Tindak

Pidana Korupsi dibutuhkan bukti-bukti yang cukup untuk menjatuhkan sanksi pidana bagi pelaku tindak pidana tersebut. pembuktian sangat diperlukan untuk membuktikan apakah perbuatan terdakwa sah melawan hukum yang berlaku atau tidak, dan salah satu hal yang seringkali luput dari perhatian dalam proses pembuktian adalah unsur niat serta unsur mens rea (mental element) pelaku tindak pidana korupsi.

Unsur Niat dan Unsur Mens Rea dalam tindak pidana korupsi sangat penting untuk diperhatikan, sebab kejahatan yang saat ini dimasukkan ke dalam katagori extra ordinary crime ini tidak semua dilakukan atas kesadaran atau ada niat namun tidak sedikit kasus korupsi yang menyeret staff atau pegawai rendahan akibat menjalankan perintah atasannya, sehingga apakah ketika seseorang yang berbuat tidak pidana karena sebuah perintah yang sebenarnya hal itu bertentangan dengan hati nurani dan tidak ada niat layak untuk dipidana atau dihukum ?

dengan latar belakang permasalahan itulah penulisan ini ingin mengungkap bagaimana hubungan antara unsur niat dan unsur mens rea dalam tindak pidana korupsi. penelitian ini dilakukan dengan menggunakan pendekatan konseptual (Conseptual Approach), menurut Prof. Dr. Peter Mahmud Marzuki, S.H.,MS, LL.M (2001 :138) bahwa pendekatan Konseptual adalah penelitian yang merujuk pada prinsip-prinsip hukum yang dikemukakan oleh pandanganpandangan sarjana ataupun doktrindoktrin hukum.

\section{I.2. Identifikasi Masalah}

berdasarkan latar belakang yang telah sedikit diuraikan di atas, penulisan ini akan fokus dalam masalah bagaimana pembuktian unsur niat dalam tindak pidana korupsi yang dikaitkan dengan unsur mens rea . dan pembahasan masalah dalam tulisan ini dibatasi dengan identifikasi masalah sebagai berikut ;

1. Pengertian Unsur Niat dan Unsur Mens Rea

2. Hubungan Unsur Niat dengan tindak pidana korupsi.

3. Pengertian Pembuktian dan Pengertian Tindak Pidana Korupsi.

\section{I.3. Maksud Dan Tujuan Penelitian} sesuai dengan identifikasi masalah yang telah diuraikan maka penulisan karya ilmiah ini memiliki maksud dan tujuan sebagai berikut ; 
1. menguraikan hubungan antara unsur niat dan unsur mens rea dalam sebuah perbuatan tindak pidana korupsi

2. untuk mengungkap bagaimana cara membuktikan bahwa sebuah perbuatan tindak pidana korupsi itu sengaja dilakukan dengan sebuah niat jahat dengan kondisi kejiwaan yang sadar atau tidak.

\section{I.4. Kegunaan Penelitian}

penulisan karya ilmiah yang mengambil topik pembuktian unsur niat yang dikaitkan dengan unsur mens rea dalam tindak pidaa korupsi ini diharapkan dapat memberikan manfaat dan kegunaan diantaranya sebagai berikut :

1. dari sudut teoritis, dengan tulisan ilmiah ini diharapkan dapat menambah wawasan pengetahuan dalam bidang hukum pidana dan hukum acara pidana khususnya dalam hal pembuktian perbuatan tindak pidana korupsi

2. kegunaan praktis dengan penelitian ini diharapkan dapat menjadi masukan dan saran konstruktif bagi penagak hukum baik kepolisian, penuntut umum, advokat maupun hakim.

\section{PEMBAHASAN}

\section{II.1. Pembuktian Dalam Hukum Acara Pidana}

Tujuan Hukum Acara Pidana adalah untuk mencari dan mendapatkan kebenaran ssetidak-tidaknya mendekati kebenaran materiil, yaitu kebenaran yang selengkap-lengkapnya dari perkara pidana dengan menetapkan ketentuan Hukum Acara Pidana secara Jujur dan tepat guna mencari siapakah pelaku yang telah melakukan suatu tindak pidana.

Azas Hukum acara pidana yang dianut di Negara Kita adalah azas praduga tak bersalah, azas ini bertujuan untuk melindungi terdakwa dari hukum yang tidak sesuai dengan kesalahannya atau sebelum adanya putusan hakim yang menyatakan atas kesalahan terdakwa.

Untuk dapat mengungkap kesalahan seorang terdakwa yang diajukan ke muka sidang, maka penuntut umum harus berusaha untuk dapat membuktikan kesalahan tersebut. sehingga penuntut umum dibebani untuk melakukan pembuktian dimana dengan alat-alat bukti yang diajukan itu membuat terang akan kebenaran suatu tindak pidana yang telah terjadi yang dilakukan oleh terdakwa yang dibawa di muka sidang. 
Berdasarkan Keputusan Menteri Kehakiman Republik Indonesia no : M.01.PW-07-03 tahun 1982 tentang pedoman pelaksanaan Undang-Undang Hukum Acara Pidana menyatakan :

tujuan dari hukum acara pidana adalah untuk mencari dan mendapatkan setidak-tidaknya mendekati kebenara materiil, ialah kebenaran yang selengkaplengkapnya dari suatu perkara pidana dengan menerapkan ketentuan hukum acara pidana secara jujur dan tepat dan bertujuan untuk mencari siapakah pelaku yang tepat yang dapat didakwakan melakukan pelanggaran hukum dan selanjutnya meminta pelaksanaan dari pengadilan guna menentukan apakah terbukti bahwa suatu tindak pidana dilakukan dan apakah orang yang didakwakan itu dapat dipersalahkan

Sedangkan M Yahya Harahap (2000:252) menegaskan bahwa pembuktian merupakan titik sentral pemeriksaan perkara dalam sidang pengadilan. pembuktian adalah ketentuan-ketentuan yang berisi penggarisan dan pedoman tentang caracara yang dibenarkan undang-undang membuktikan kesalahan yang didakwakan kepada terdakwa. pembuktian juga mengatur alat-alat bukti yang dibenarkan undang-undang yang boleh digunakan hakim membuktikan kesalahan yang didakwakan.
Persoalan terbukti atau tidaknya suatu perbuatan tindak pidana di muka sidang, hakimlah yang memberikan penilaian mengenai kekuatan dari alat bukti yang diajukan oleh penuntut umum, akan tetapi hakim tidak boleh menjatuhkan pidana kepada seseorang kecuali dengan sekurang-kurangnya dua alat bukti yang sah, selain itu yang juga harus menjadi pertimbagan adalah mengenai niat dan kondisi kejiwaan terdakwa saat melakukan tindak pidana itu.

Pembuktian bertujuan untuk mengungkap suatu tindak pidana, hukum pembuktian merupakan bagia dari hukum acara pidana atau hukum formal, sedangkan hukum materilnya yaitu mengenai perbuatan-perbuatan yang dilanggarnya. hukum pidana materill ini diatur dalam KUHP. dan Hukum Materiil yang mengatur tindak pidana korupsi adalah Undang-Undang RI nomor 31 tahun 1999 sebagaimana diubah dengan Undang-undang RI nomor 20 tahun 2001 tentang perubahan atas Undang-undang $\mathrm{RI}$ nomor 31 tahun 1999.

\section{II.2. Delik Pidana dan Unsur Niat}

Delict berasal dari bahasa latin yaitu delictum (delik) disebut strafbaar feit atau tindak pidana. Dalam pengertian lain menurut oleh Van Hamel 
menyebutkan bahwa strafbaar feit adalah kelakuan orang (menselijke gedraging) yang dirumuskan dalam wet, yang bersifat melawan hukum, yang patut di pidana (straaf waardig) dan dilakukan dengan kesalahan, dengan demikian Delik adalah suatu perbuatan atau tindakan yang terlarang dan diancam dengan hukuman atau pidana oleh undang-undang. sedangkan Delik menurut para ahli diantarnya dikemukakan oleh beberapa pakar hukum sebagai berikut :

1. Achmad Ali : Pengertian umum tentang semua perbuatan yang melanggar hukum ataupun UndangUndang dengan tidak membedakan apakah pelanggaran itu dibidang hukum privat ataupun hukum publik termasuk hukum pidana.

2. Utrecht memakai istilah peristiwa pidana karena istilah peristiwa itu meliputi suatu perbuatan (handelen atau doen) atau suatu melalaikan (verzuin atau nalaten) maupun akibatnya (keadaan yang ditimbulkan oleh karena perbuatan atau melalaikan itu), dan peristiwa pidana adalah suatu peristiwa hukum, yaitu suatu peristiwa kemasyarakatan yang membawa akibat yang diatur oleh hukum

3. Andi Zainal Abidin Farid : menggunakan istilah peristiwa pidana dengan rumusan peristiwa pidana adalah suatu perbuatan yang diancam pidana, melawan hukum dilakukan dengan kesalahan oleh orang yang dapat dipertanggungjawabkan atas perbuatan itu.

4. Menurut Moeljatno : memakai istilah perbuatan pidana yang dirumuskan yang diartikan sebagai perbuatan yang dilarang oleh suatu aturan hukum disertai ancaman (sanksi) berupa pidana tertentu, bagi barangsiapa yang melanggar larangan tersebut.

5. Prof. Simons : mengartikan delik sebagai suatu tindakan melanggar hukum yang telah dilakukan dengan sengaja ataupun tidak sengaja oleh seseorang yang tindakannya tersebut dapat dipertanggungjawabkan dan oleh undang-undang telah dinyatakan sebagai suatu tindakan yang dapat dihukum

Berkaitan dengan asas hukum pidana yaitu Geen straf zonder schuld, actus non facit reum nisi mens sir rea, bahwa tidak dipidana jika tidak ada kesalahan, maka pengertian tindak pidana itu terpisah dengan yang dimaksud pertanggungjawaban tindak pidana. Tindak pidana hanyalah menunjuk kepada dilarang dan 
diancamnya perbuatan itu dengan suatu pidana, kemudian apakah orang yang melakukan perbuatan itu juga dijatuhi pidana sebagaimana telah diancamkan akan sangat tergantung pada soal apakah dalam melakukan perbuatannya itu si pelaku juga mempunyai kesalahan.

Dalam kebanyakan rumusan tindak pidana, unsur kesengajaan atau yang disebut dengan opzet merupakan salah satu unsur yang terpenting. Dalam kaitannya dengan unsur kesengajaan ini, maka apabila didalam suatu rumusan tindak pidana terdapat perbuatan dengan sengaja atau biasa disebut dengan opzettelijk, maka unsur dengan sengaja ini menguasai atau meliputi semua unsur lain yang ditempatkan dibelakangnya dan harus dibuktikan.

Sengaja berarti juga adanya kehendak yang disadari yang ditujukan untuk melakukan kejahatan tertentu. Maka berkaitan dengan pembuktian bahwa perbuatan yang dilakukannya itu dilakukan dengan sengaja, terkandung pengertian menghendaki dan mengetahui atau biasa disebut dengan willens en wetens. Yang dimaksudkan disini adalah seseorang yang melakukan suatu perbuatan dengan sengaja itu haruslah memenuhi rumusan willens atau haruslah menghendaki apa yang ia perbuat dan memenuhi unsur wettens atau haruslah mengetahui akibat dari apa yang ia perbuat.

Disini dikaitkan dengan teori kehendak yang dirumuskan oleh Von Hippel maka dapat dikatakan bahwa yang dimaksudkan dengan sengaja adalah kehendak membuat suatu perbuatan dan kehendak untuk menimbulkan suatu akibat dari perbuatan itu atau akibat dari perbuatannya itu yang menjadi maksud dari dilakukannya perbuatan itu.

Jika unsur kehendak atau menghendaki dan mengetahui dalam kaitannya dengan unsur kesengajaan tidak dapat dibuktikan dengan jelas secara materiil -karena memang maksud dan kehendak seseorang itu sulit untuk dibuktikan secara materiilmaka pembuktian adanya unsur kesengajaan dalam pelaku melakukan tindakan melanggar hukum sehingga perbuatannya itu dapat dipertanggungjawabkan kepada si pelaku seringkali hanya dikaitkan dengan keadaan serta tindakan si pelaku pada waktu ia melakukan perbuatan melanggar hukum yang dituduhkan kepadanya tersebut.

Perumusan delik (tindak pidana) korupsi dalam "aturan khusus" hanya merupakan bagian dari keseluruhan sistem hukum pidana (sistem 
pemidanaan). Perumusan delik (baik unsur-unsurnya, jenis deliknya, maupun jenis pidana/sanksi dan lamanya pidana) bukan merupakan sistem yang berdiri sendiri. Oleh karena itu perumusan delik itu masih harus ditunjang oleh bagianbagian sistem lainnya, yaitu bagian aturan/pedoman dan asas-asas pemidanaan yang ada di dalam aturan umum KUHP atau aturan khusus dalam UU khusus yang bersangkutan dalam hal ini, Undang-Undang Nomor 31Tahun 1999 Jo. UU No.20 Tahun 2001.

Perbuatan korupsi merupakan delik pidana formiil yaitu adanya tindak pidana korupsi cukup dengan dipenuhinya unsur-unsur perbuatan yang dirumuskan, bukan dengan timbulnya akibat. Hal ini dijelaskan dalam Undang-Undang Nomor 31 tahun 1999, meskipun hasil korupsi telah dikembalikan kepada negara, pelaku tindak pidana korupsi tetap diajukan ke pengadilan dan tetap dipidana, yakni tercantum dalam pasal 4: "Pengembalian kerugian keuangan negara atau perekonomian negara tidak menghapuskan dipidananya pelaku tindak pidana sebagaimana dimaksud dalam Pasal 2 dan Pasal 3."

Agar dapat menjangkau berbagai macam perbuatan penyimpangan keuangan negara atau perekonomian negara yang semakin canggih dan rumit, maka tindak pidana yang diatur dalam Undang-undang ini dirumuskan sedemikian rupa sehingga meliputi perbuatan-perbuatan memperkaya diri sendiri atau orang lain atau suatu badan (korporasi) secara "melawan hukum" dalam pengertian formil dan materiil. Dengan perumusan tersebut, pengertian melawan hukum dalam tindak pidana korupsi dapat pula mencakup perbuatan-perbuatan tercela yang menurut masyarakat harus dituntut dan dipidana.

Penjelasan Pasal 2 ayat (1), yang dimaksud dengan "secara melawan hukum" dalam pasal ini mencakup perbuatan melawan hukum dalam arti formil maupun dalam arti materiil, yaitu walaupun perbuatan tersebut tidak diatur dalam peraturan perundangundangan, namun apabila perbuatan tersebut dianggap tercela karena tidak sesuai dengan rasa keadilan atau norma-norma kehidupan sosial dalam masyarakat, maka perbuatan tersebut dapat dipidana. Rumusan tindak pidana korupsi yang diatur dalam Undang-undang Nomor 3 Tahun 1971 dalam prakteknya sering ditafsirkan sebagai delik materiil, yakni delik yang selesai jika telah timbul akibat merugikan keuangan negara atau perekonomian negara. Sehingga, apabila pelaku mengembalikan hasil korupsi yang dilakukan, maka unsur 
kerugian negara dianggap sudah tidak ada lagi, sehingga pelaku tindak pidana korupsi tidak diajukan ke pengadilan atau dipidana. Sebaliknya, dengan delik formil yang dianut Undang-undang Nomor 31 Tahun 1999 yang telah diubah oleh Undang-Undang Nomor 20 tahun 2001, meskipun hasil korupsi telah dikembalikan kepada negara, pelaku tindak pidana korupsi tetap diajukan ke pengadilan dan dapat dipidana.

II.3. Hubungan Niat dan Mens Rea Dengan Tindak Pidana

Bahwa suatu perbuatan dianggap telah melanggar hukum dan dapat dikenakan sanksi pidana, harus dipenuhi dua unsur, yaitu adanya unsur actus reus (physical element) dan unsur mens rea (mental element). Unsur actus reus adalah esensi dari kejahatan itu sendiri atau perbuatan yang dilakukan, sedangkan unsur mens rea adalah sikap batin pelaku pada saat melakukan perbuatan.

Dalam ilmu hukum pidana, perbuatan lahiriah itu dikenal sebagai actus reus, sedangkan kondisi jiwa atau sikap kalbu dari pelaku perbuatan itu disebut mens rea. Jadi actus reus adalah merupakan elemen luar (external element), sedangkan mens rea adalah unsur kesalahan (fault element) atau unsur mental (mental element).

Seseorang dapat dipidana tidak cukup hanya karena orang itu telah melakukan perbuatan yang bertentangan dengan hukum atau bersifat melawan hukum. Sehingga, meskipun perbuatannya memenuhi rumusan delik dalam peraturan perundang-undangan dan tidak dibenarkan (an objective breach of a penal provision) namun hal tersebut belum memenuhi syarat untuk penjatuhan pidana. Hal ini karena harus dilihat sikap batin (niat atau maksud tujuan) pelaku perbuatan pada saat melakukan perbuatan yang bertentangan dengan hukum atau bersifat melawan hukum tersebut.

Di beberapa negara, perbuatan dan sikap batin seseorang dipersatukan dan menjadi syarat adanya suatu perbuatan pidana. Zainal Abidin Farid berpendapat bahwa unsur actus reus yaitu perbuatan harus didahulukan. Setelah diketahui adanya perbuatan pidana sesuai rumusan undang-undang selanjutnya barulah diselidiki tentang sikap batin pelaku atau unsur mens rea. Dengan demikian maka unsur perbuatan pidana harus didahulukan, selanjutnya apabila terbukti barulah mempertimbangkan tentang kesalahan terdakwa 
yang merupakan unsur pertanggungjawaban pidana.

Utrecht berpandangan Mens Rea adalah sikap batin pelaku perbuatan pidana. Berbeda dengan actus reus yang menyangkut perbuatan yang melawan hukum (unlawful act), mens rea mencakup unsur-unsur pembuat tindak pidana yaitu sikap batin yang disebut unsur subyektif suatu tindak pidana atau keadaan psikis pembuat

Delik disebut sebagai unsur subyektif apabila unsur-unsurnya terbukti maka berarti terbuktinya pertanggung-jawaban pembuat delik. Unsur-unsurnya adalah kemampuan bertanggungjawab, kesalahan dalam arti luas, tidak adanya alasan pemaaf yang semuanya melahirkan schuld-haftigkeit uber den tater yaitu hal dapat dipidananya pembuat delik.

Perbedaan antara unsur-unsur perbuatan melawan hukum atau perbuatan kriminal dan pertanggungjawaban pembuat delik tidak berarti bahwa keduanya tidak saling berhubungan. $\mathrm{Hal}$ ini harus diingat bahwa onrechtmatigheid atau hal melanggar hukum itu sebagai ketentuan timbul dari norma yang atas pelanggarannya dinyatakan sebagai dapat dihukum. Di dalam rumusan dari sesuatu perbuatan yang dapat dihukum, maka unsur kesengajaan dapat dianggap sebagai termasuk di dalamnya karena menurut ketentuan hal tersebut memang disyaratkan.

Perbuatan melawan hukum dianggap sebagai unsur dari setiap tindak pidana, hal ini berdasarkan pendapat doktrin Satochid Kartanegara membedakan dalam dua bentuk yaitu:

1. Wederrechtelijk formil yaitu apabila sesuatu perbuatan dilarang dan diancam dengan hukuman oleh undang-undang.

2. Wederrechtelijk materiil yaitu sesuatu perbuatan mungkin wederrechtelijk walaupun tidak dengan tegas dilarang dan diancam dengan hukuman oleh undang-undang.

Dengan demikian wederrechte-lijk formil bersandar pada undang-undang, sedangkan wederrechtelijk materiil tidak bersandarkan pada undang-undang, melainkan pada asas-asas umum yang terdapat di dalam lapangan hukum, atau apa yang dinamakan algemene beginselen.

Sedangkan beberapa ahli hukum memberikan arti sebagai berikut : Simons menyatakan bahwa sebagai dasar pertanggung jawaban pidana adalah kesalahan yang terdapat pada jiwa pelaku dalam hubungannya dengan kelakuannya yang dapat dipidana dan 
berdasarkan kejiwaannya karena kelakuannya.

Dengan demikian untuk adanya kesalahan pada pelaku harus dicapai dan ditentukan terlebih dahulu beberapa hal yang menyangkut pelaku, yaitu; Kemampuan bertanggung jawab (toerekenings-vatbaarheid), Hubungan kejiwaan (psychologische betrekking) antara pelaku dan akibat yang ditimbulkan Dolus atau Culpa.

Sedangkan Utrecht menyatakan bahwa pertanggung jawaban pidana atau kesalahan menurut hukum pidana (schuld in ruimte zin) terdiri atas tiga anasir yaitu: Kemampuan bertanggung jawab (toerekeningsvatbaarheid) dari pembuat Suatu sikap psikhis pembuat berhubung dengan kelakuannya, yaitu Kelakuan disengaja (anasir sengaja), dan Kelakuan kurang berhati-hati atau lalai (anasir kealpaan) atau culpa (schuld in enge zin). Tidak ada alasanalasan yang menghapuskan pertanggung jawaban pidana pembuat (anasir toerekeningsvatbaarheid).

Maka dari uraian tersebut diatas, dapat dikatakan bahwa jika ada hubungan antara batin pelaku dengan akibat yang timbul karena perbuatannya itu atau ada hubungan lahir yang merupakan hubungan kausal antara perbuatan pelaku dengan akibat yang dilarang itu, maka hukuman pidana dapat dijatuhkan kepada si pelaku atas perbuatan pidananya itu.

\section{KESIMPULAN DAN SARAN}

III.1. Kesimpulan

berdasarkan hasil pembahasan yang telahh diuraikan dalam tulisan ini maka dapat disimpulkan sebagai berikut :

1. Berkaitan dengan asas hukum pidana yaitu Geen straf zonder schuld, actus non facit reum nisi mens sir rea, bahwa tidak dipidana jika tidak ada kesalahan, maka pengertian tindak pidana itu terpisah dengan yang dimaksud pertanggungjawaban tindak pidana. Tindak pidana hanyalah menunjuk kepada dilarang dan diancamnya perbuatan itu dengan suatu pidana, kemudian apakah orang yang melakukan perbuatan itu juga dijatuhi pidana sebagaimana telah diancamkan akan sangat tergantung pada soal apakah dalam melakukan perbuatannya itu si pelaku juga mempunyai kesalahan.

2. Seseorang dapat dipidana tidak cukup hanya karena orang itu telah melakukan perbuatan yang bertentangan dengan hukum atau bersifat melawan hukum. Sehingga, meskipun perbuatannya memenuhi rumusan delik dalam peraturan perundang-undangan dan tidak dibenarkan (an objective breach of a penal provision) namun hal tersebut 
belum memenuhi syarat untuk penjatuhan pidana sesuai dengan asas Geen straf zonder schuld, actus non facit reum nisi mens sir rea

3. pertanggung jawaban pidana atau kesalahan menurut hukum pidana (schuld in ruimte zin) terdiri atas tiga anasir yaitu: Kemampuan bertanggung jawab (toerekeningsvatbaarheid) dari pembuat Suatu sikap psikhis pembuat berhubung dengan kelakuannya, yaitu Kelakuan disengaja (anasir sengaja), dan Kelakuan kurang berhati-hati atau lalai (anasir kealpaan) atau culpa (schuld in enge zin). Tidak ada alasan-alasan yang menghapuskan pertanggung jawaban pidana pembuat (anasir toerekeningsvatbaarheid).

\section{III.2. Saran}

Berdasarkan hasil dari uraian dan kesimpulan diatas penulis mengajukan saran sebagai berikut : Pembuktian merupakan hal yang sangat menentukan apakah seseorang yang berbuat kesalahan dapat dijatuhkan pidana atau tidak, sehingga seharusnya didalam proses pembuktian bukan saja alat bukti yang diajukan namun juga harus mempertimbangkan dan membuktikan unsur niat dan mens rea, karena perbuatan dianggap telah melanggar hukum dan dapat dikenakan sanksi pidana, harus dipenuhi dua unsur, yaitu adanya unsur actus reus (physical element) dan unsur mens rea (mental element)

\section{DAFTAR PUSTAKA}

\section{Sumber Buku Primer :}

Hamzah, Andi, Pengantar Hukum Acara Pidana Indonesia, Ghalia Indonesia. Jakarta, 1984.

Harahap, M Yahya, Pembahasan Permasalahan Dalam Penerapan KUHAP, Jilid I, Penyidikan dan Penuntutan, Edisi Kedua, Sinar Grafika, Jakarta, 2000.

Marzuki, Peter Mahmud, Prof, Dr, Penelitian Hukum. Kencana Prenada Media Group. Jakarta, 2011.

Moeljatno, Azas-Azas Hukum Pidana. PT. Bina Aksara, Jakarta, 1987.

Lamintang, PAF, Dasar-dasar Hukum Pidana Indonesia, Sinar Baru, Bandung, 1984.

Sasangka, Hari dan Lily Rosita, Hukum Pembuktian Dalam Perkara Pidana, Mandar Maju, Bandung, 2003.

\section{Perundang-Undangan :}

1. Soesilo, R terjemahan Kitab Undangundang Hukum Pidana beserta lengkap dengan komentarkomentarnya pasal demi pasal. politea . Bogor 1991.

2. Undang-Undang Nomor 8 tahun 1981 tentang Hukum Acara Pidana. 
